\title{
B4GALT6 Gene
}

National Cancer Institute

\section{Source}

National Cancer Institute. B4GALT6 Gene. NCI Thesaurus. Code C103937.

This gene plays a role in glycosphing olipid synthesis. 